Brit. J. industr. Med., 1965, 22, 261.

\title{
MESOTHELIOMA OF PLEURA AND PERITONEUM FOLLOWING EXPOSURE TO ASBESTOS IN THE LONDON AREA
}

\author{
BY \\ MURIEL L. NEWHOUSE and HILDA THOMPSON \\ From the Department of Occupational Health and Applied Physiology, \\ London School of Hygiene and Tropical Medicine
}

(RECEIVED FOR PUBLICATION FEBRUARY 11, 1965)

\begin{abstract}
A series of 83 patients from the London Hospital with a diagnosis of mesothelioma confirmed by necropsy or biopsy has been studied for possible exposure to asbestos. The series consisted of 41 men and 42 women; 27 of the patients had peritoneal and 56 pleural tumours. The earliest death recorded was in 1917, but only 10 of the series died before 1950 and 40 (48\%) between 1960 and 1964.

In 76 of the series full occupational and residential histories were obtained. Forty (52.6\%) gave a history of occupational or domestic (living in the same house as an asbestos worker) exposure to asbestos compared with nine (11.8\%) out of 76 patients from the same hospital suffering from other diseases $(P<0.001)$. None of the 17 suspected cases of mesothelioma, rejected on pathological grounds, was found to have had any exposure to asbestos. There was also evidence that neighbourhood exposures may be important. Among those with no evidence of occupational or domestic exposures, $30.6 \%$ of the mesothelioma patients and $7.6 \%$ of the in-patients with other diseases lived within half a mile of an asbestos factory $(P<0.01)$. Out of the 31 patients with occupational exposures only 10 were in jobs scheduled under the Asbestos Regulations of 1931. The interval between first exposure and the development of the terminal illness of mesothelioma ranged between 16 and 55 years.

In 47 patients in the mesothelioma series, lung tissue or sputum was available for examination. In $30(62.5 \%)$, either asbestosis or asbestos bodies were present.
\end{abstract}

In recent years, the association between exposure to asbestos dust and cancer of the lung and other malignant neoplasms has been the subject of much research (leading article, 1964). Wagner, Sleggs, and Marchand (1960) described the occurrence of mesothelioma of the pleura in those exposed to crocidolite asbestos in the mining districts of South Africa, and this has stimulated further studies of the occupational histories of patients suffering from this tumour (Owen, 1964; Fowler, Sloper, and Warner, 1964).

The present investigation concerns patients in whom mesothelioma had been diagnosed at the London Hospital during the past $\mathbf{5 0}$ years. After examining the necropsy and biopsy specimens held in the pathology department, Hourihane (1964) confirmed a diagnosis of mesothelioma in 83 patients, of whom 41 were men and 42 women. Thirty-one of the men had pleural tumours and 10 peritoneal; among the women, 25 had pleural and 17 peritoneal tumours.

The aim of this study has been to establish the occupational histories of these patients and to trace any other possible exposure to asbestos. There were four surviving patients at the outset of the investigation, but these have subsequently died. The earliest date of death in the series was 1917; 10 died before 1950, 33 between 1950 and 1959, and the remaining 40 in the past four and a half years. The youngest patient died at the age of 33 , and nearly half were dead before the age of 55 (Table 1).

\section{Clinical Features}

The ward notes of 65 of the patients were available and give a picture of a disease with a consistent symptomatology. Among those with pleural 
TABLE 1

AGE AT DEATH OF 83 PATIENTS WITH MESOTHELIAL TUMOURS

\begin{tabular}{c|c|c|c|c}
\hline \multirow{2}{*}{ Age (yr.) } & \multicolumn{2}{|c|}{ Male } & \multicolumn{2}{c}{ Female } \\
\cline { 2 - 5 } & No. & $\%$ & No. & $\%$ \\
\hline$<34$ & 2 & 4.9 & 1 & 2.4 \\
$35-$ & 7 & 17.1 & 6 & 14.3 \\
$45-$ & 15 & 36.6 & 9 & 21.4 \\
$55-$ & 10 & 24.4 & 18 & 42.9 \\
$65+$ & 7 & 17.1 & 8 & 19.0 \\
\hline
\end{tabular}

tumours, the commonest presenting symptom was the rapid onset of extreme shortness of breath due to the formation of a massive pleural effusion. Pain was a prominent feature, either described as a dull ache, sometimes due to invasion of the ribs or. vertebrae, or sometimes sharp and radiating, suggesting nerve involvement. Tumours in the chest wall were not uncommon, occurring either in previous operation scars or by direct invasion of the chest wall. The symptomatology of the peritoneal tumours was more varied. In some patients the presenting symptom was pain on defaecation or micturition. Diffuse upper abdominal pain was very common, and swelling of the abdomen due to ascites was always present terminally. The methods of treatment included pneumonectomy, decortication of the lung, deep $x$-ray therapy, instillation of radioactive gold, and cytotoxic drugs. They were used alone or in combination but had little effect on the course of the disease. Half of the patients suffering from pleural mesothelioma died within one year of the onset of symptoms, a further third within two years, and only one patient survived for more than three years. The course of those with peritoneal tumours appeared to be equally rapid. Eight of the patients died within six months of the onset of symptoms.

\section{Sources of Information on Occupation and Residence}

In addition to the ward notes, some of which gave good occupational histories, there were three other sources of information: the patient's general practitioner; the records of an asbestos factory in the area; and personal interviews with patients or their surviving relatives.

As a first step, general practitioners were circulated with an explanatory letter asking them to complete a form giving details of the occupations of patients and their immediate relatives. Within two months $65 \%$ of the doctors had replied. In two cases a hitherto unknown exposure to asbestos was revealed; in others the name and address of a surviving relative were given, but in the majority the doctor was unable to give information because, on the death of the patient, the notes had been returned to the local executive council of the National Health Service, where they were destroyed within a period of three years.

In one of the asbestos factories a file was kept with detailed records of all employees since it started in 1913. The names of all patients were checked with these files. Nine men and nine married women (after their maiden names had been ascertained from relatives) were identified without difficulty. The exact dates of employment of these 18 patients and the jobs they had done were obtained from the records of the factory.

The four patients alive at the beginning of the investigation were interviewed personally. A few relatives were contacted by post, but the relatives of 68 patients were interviewed by one of us (H.T.) at their homes situated mostly in the East End of London. Not only was an occupational history of the patient, the spouse, sons and daughters, and father taken, but past addresses were also recorded. The interviews lasted for at least an hour. To recall events of 30 or 40 years ago it was often necessary to explore the residential and occupational histories of all members of the family.

Exposure to Asbestos in Three Groups of Patients Suffering from Other Diseases

For comparison with the mesothelioma patients, three further groups of patients suffering from other diseases were investigated.

The first group was selected from the patients in the medical and surgical wards of the hospital during the early summer of 1964 ('in-patient' series). Each patient in the mesothelioma series who had been traced was matched with an in-patient of the same sex born in the same five-year period. As there was a dearth of male patients over 75 years of age in the hospital, a sample of six patients of this age and older was taken from a neighbouring geriatric hospital.

The second group were those who had originally been filed in the pathology department of the hospital as cases of mesothelioma but in whom the diagnosis was subsequently rejected on pathological grounds by Hourihane (1964) ('rejected series'). As it had proved extremely difficult to locate the relatives of those who died before 1950 , attempts were made only to trace the three survivors in this group and the 14 who died after 1950 .

The in-patient series, already described, were all admitted to hospital in 1964 . The patients with mesothelioma were admitted to the same hospital over a period of 47 years during which there might have been a substantial change both in the residential 
areas and social classes of patients attending the London Hospital. Thus, a third group of patients was taken from the hospital records matched by date of admission as well as date of birth and sex with the patients in the mesothelioma series. Their places of residence and occupations were extracted for comparison with those of the in-patient series.

\section{Results}

Details of the 83 patients in the mesothelioma series are given in the Appendix. No information about past domestic and occupational histories was available for seven patients. Among the remaining $76,40(52.6 \%)$ gave a history of exposure to asbestos compared with only nine $(11.8 \%)$ of the 'in-patient' series (Table 2). The difference in this proportion is

TABLE 2

TYPES OF EXPOSURE TO ASBESTOS OF $76^{*}$ PATIENTS WITH MESOTHELIOMA AND 76 IN-PATIENTS WITH OTHER DISEASES

\begin{tabular}{|c|c|c|c|c|}
\hline \multirow[t]{2}{*}{ Type of Exposure } & \multicolumn{2}{|c|}{$\begin{array}{l}\text { Mesothelioma } \\
\text { Series }\end{array}$} & \multicolumn{2}{|c|}{$\begin{array}{l}\text { 'In-patient' } \\
\text { Series }\end{array}$} \\
\hline & No. & $\%$ & No. & $\%$ \\
\hline $\begin{array}{l}\text { Employed at one asbestos } \\
\text { factory } \\
\text { Delivered goods to factory }\end{array}$ & $\left.\begin{array}{r}18 \\
1\end{array}\right\}$ & $25 \cdot 0$ & 1 & $1 \cdot 3$ \\
\hline $\begin{array}{l}\text { Employed at other asbestos } \\
\text { factories }\end{array}$ & 4 & $5 \cdot 3$ & 1 & $1 \cdot 3$ \\
\hline Insulators and laggers & 8 & $10 \cdot 5$ & 4 & $5 \cdot 3$ \\
\hline Relative worked with asbestos & 9 & $11 \cdot 8$ & 1 & $1 \cdot 3$ \\
\hline $\begin{array}{l}\text { Dockers handling asbestos } \\
\text { cargo }\end{array}$ & $\mathbf{0}$ & - & 2 & $2 \cdot 6$ \\
\hline $\begin{array}{l}\text { No history } \begin{array}{l}\text { of work } \\
\text { domestic } \\
\text { exposure }\end{array} \\
\text { asbestos }\end{array}$ & 36 & $47 \cdot 4$ & 67 & $88 \cdot 2$ \\
\hline
\end{tabular}

Positive exposures to asbestos in mesothelioma series versus positive histories in in-patient series:

$$
\chi^{2}=27.11, \text { P }<0.001
$$

* Seven cases of mesothelioma could not be traced and are omitted from this table.

statistically highly significant $\left(\chi^{2}=27 \cdot 11 ; \mathrm{P}<\right.$ 0.001 ). This result is unlikely to be unduly influenced by the two groups of patients not being matched for year of admission to hospital, since there was no significant difference either in the areas of residence or in the occupations of the patients admitted in 1964 and those admitted between 1917 and 1964 . Comparing the confirmed and rejected patients in the mesothelioma group who died after 1950, $36(50 \%)$ of the confirmed and none of the 17 rejected cases gave a history of exposure to asbestos (Table 3 ). This difference is statistically highly significant $\left(\chi^{2}=11.83 ; \mathrm{P}<0.001\right)$.
TABLE 3

EXPOSURE TO ASBESTOS OF CONFIRMED AND REJECTED CASES OF MESOTHELIOMA SURVIVING AFTER JANUARY 1950

\begin{tabular}{l|c|c}
\hline \multicolumn{1}{c|}{ Exposure to Asbestos } & Diagnosis of Mesothelioma \\
\cline { 2 - 3 } & Confirmed & Rejected \\
\hline Exposure positive & 36 & 0 \\
\hline $\begin{array}{l}\text { No work or domestic contact } \\
\text { found }\end{array}$ & 35 & 16 \\
\hline Untraced & 1 & 1 \\
\hline
\end{tabular}

$\chi^{2}=11.83, \mathrm{P}<0.001$

\section{Mesothelioma Series}

Occupational Exposures.-There are details available for the 18 mesothelioma patients who had worked at one asbestos factory which used crocidolite asbestos with small amounts of chrysotile and first introduced amosite in 1926. Eleven started work before 1933 (the year when the asbestos regulations controlling the manufacture of asbestos goods and the protection of asbestos workers became effective), and seven started work between the beginning of 1933 and the end of 1942 . The occupations of these workers and the type of asbestos they used are shown in Table 4. All of the 17 for whom details were available had used crocidolite asbestos. Five of the occupations listed are not scheduled as

TABLE 4

JOBS OF 17* PATIENTS WITH MESOTHELIOMA EMPLOYED AT ONE ASBESTOS FACTORY

\begin{tabular}{|c|c|c|c|c|}
\hline $\begin{array}{l}\text { Statutory } \\
\text { Obligations }\end{array}$ & Job & Male & Female & Material \\
\hline $\begin{array}{l}\text { Subject to } \\
\text { regulations }\end{array}$ & $\begin{array}{l}\text { Spinning } \\
\text { Carding } \\
\begin{array}{c}\text { Clothing and } \\
\text { weaving }\end{array} \\
\text { Disintegrating } \\
\text { and opening }\end{array}$ & $\begin{array}{l}0 \\
1 \\
1 \\
2\end{array}$ & $\begin{array}{l}4 \\
1 \\
0\end{array}$ & $\begin{array}{c}\text { Crocidolite } \\
\text { Crocidolite } \\
\begin{array}{c}\text { Crocidolite, } \\
\text { chrysotile, }\end{array} \\
\text { amosite } \\
\begin{array}{c}\text { Crocidolite, } \\
\text { chrysotile, } \\
\text { amosite }\end{array}\end{array}$ \\
\hline $\begin{array}{l}\text { Not subject to } \\
\text { regulations }\end{array}$ & 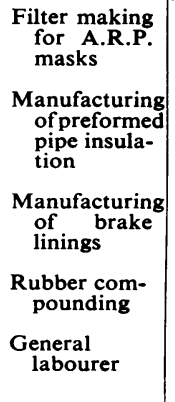 & $\begin{array}{l}1 \\
0\end{array}$ & o & $\begin{array}{l}\text { Crocidolite } \\
\text { Crocidolite } \\
\text { Crocidolite } \\
\begin{array}{c}\text { Crocidolite, } \\
\text { chrysotile }\end{array} \\
\begin{array}{c}\text { Crocidolite, } \\
\text { chrysotile, } \\
\text { amosite }\end{array}\end{array}$ \\
\hline
\end{tabular}

*Employment history not available for one female patient. 
requiring medical supervision under the Asbestos Regulations (1931).

Four patients were working at other factories making all types of asbestos goods. One had been employed in a wagon works sawing asbestos sheets for partitions. Except for one, a woman employed in insulating electrodes with crocidolite, the types of asbestos used in these other factories are not known.

The eight heating engineers and laggers were all men. Three had been employed in dockyards on ship repairs, two in various types of lagging, one in a power station, one installing hospital sterilizing equipment, and one installing central heating. All were consistently employed on this type of work for more than 20 years, but, in some, exposure to asbestos was intermittent.

Domestic Exposures.-The group of nine, seven women and two men, whose relatives worked with asbestos, are of particular interest. The most usual history was that of the wife who washed her husband's dungarees or work clothes. In one instance a relative said that the husband, a docker, came home 'white with asbestos' every evening for three or four years and his wife brushed him down. The two men in this group, when boys of 8 or 9 years old, had sisters who were working at an asbestos factory. One of these girls worked as a spinner from 1925 to 1936 . In 1946 she died of asbestosis. The press report of the inquest states: 'She used to return home from work with dust on her clothes'. Her brother had apparently no other exposure to asbestos; he started work as a shop assistant, then became a sawyer of iron girders until 1948 when he worked as a loader of groceries in the docks for five years (but never on dusty cargoes) and then returned to sawing iron girders. He died in 1956 of a pleural mesothelioma.

\section{In-patient Series}

Occupational and Domestic Exposures.-Two of this series had worked in asbestos factories and four had been employed as laggers. The husband of another was employed at an asbestos factory for three years, and two dockers in this group gave histories of handling asbestos cargoes from time to time throughout their working life.

The diagnoses of these patients have been grouped into seven categories (Table 5). The patients with a positive history of exposure are scattered throughout the various diagnostic groups, and there is no indication that exposure to asbestos could be related to the disease which had caused their admission.

Neighbourhood Exposures of Mesothelioma and In-patient Series.-The 36 patients with meso-
TABLE 5

DISEASE GROUPS OF PATIENTS IN THE IN-PATIENT SERIES

\begin{tabular}{l|c|c}
\hline \multicolumn{1}{c|}{ Disease Group } & $\begin{array}{c}\text { No. of } \\
\text { Patients }\end{array}$ & $\begin{array}{c}\text { No. with } \\
\text { Exposure to } \\
\text { Asbestos }\end{array}$ \\
\hline $\begin{array}{l}\text { Cardiovascular } \\
\text { Metabolic }\end{array}$ & 21 & 3 \\
Reticulo-endothelial (including & 9 & 0 \\
anaemias) & 8 & 2 \\
Gastro-intestinal (excluding cancers) & 6 & 2 \\
Respiratory (excluding cancers) & 3 & 0 \\
All neoplasms & 18 & 1 \\
Other & 11 & 1 \\
\hline Total & 76 & 9 \\
\hline
\end{tabular}

thelioma and the 67 patients in the 'in-patient' series, who had neither an occupational exposure nor a relative living in the home working with asbestos, might have been exposed to asbestos dust because they lived in the immediate vicinity of an asbestos factory.

One factory, where more than one-fifth of the mesothelioma patients were employed, opened in 1913, having been situated nearer the centre of London for the previous seven years. There were three affected female patients living within half a mile of the factory during the time it was in production at its first site. When it opened they were children between 5 and 7 years old. At the present site, there were eight patients living within a halfmile radius of the factory. One man was born within a quarter of a mile of the factory and remained at the same address for 16 years. The other seven were women, and all except one were children when the factory opened. The seventh was 23 years of age and remained in the same house until she died 48 years later. She is the only patient who had neither occupational nor household exposure but in whom asbestos bodies were found in the lungs at necropsy.

Among the 'in-patient' series, one patient lived near the factory at its previous site and four others lived near its present site. One patient was 22 years old when she moved into the neighbourhood in 1915. She disliked it and, when interviewed, complained impartially about the dust from the asbestos factory and the rats in the house.

TABLE 6

RESIDENCE OF PATIENTS WITH NO OCCUPATIONAL OR DOMESTIC EXPOSURE TO ASBESTOS

\begin{tabular}{|c|c|c|c|c|c|}
\hline \multirow[t]{2}{*}{ Series } & \multicolumn{2}{|c|}{$\begin{array}{c}\text { Lived Within } \\
\frac{1}{\frac{1}{2}} \text { mile of } \\
\text { Asbestos Factory }\end{array}$} & \multicolumn{2}{|c|}{$\begin{array}{l}\text { Lived More Than } \\
\frac{1}{2} \text { mile from } \\
\text { Asbestos Factory }\end{array}$} & \multirow[t]{2}{*}{ Total } \\
\hline & No. & $\%$ & No. & $\%$ & \\
\hline Mesothelioma & 11 & $30 \cdot 6$ & 25 & $69 \cdot 4$ & 36 \\
\hline In-patient & 5 & $7 \cdot 5$ & 62 & $92 \cdot 5$ & 67 \\
\hline
\end{tabular}


Thus, among those with no occupational or domestic exposures to asbestos, there are $11(30.6 \%)$ patients in the mesothelioma series and five $(7.6 \%)$ in the 'in-patient' series who lived within half a mile of an asbestos factory in the area (Table 6). The difference in the proportion of patients in the two series who lived in the vicinity of the factory and had had no other exposure to asbestos is statistically significant $\left(\chi^{2}=7 \cdot 85 ; \mathrm{P}<0.01\right)$.

Date of First Exposure and Interval Before Death in Mesothelioma Series.-Fifty-one men and women had been exposed to asbestos, including those who lived near the main asbestos factory. The duration of exposure varied widely, ranging from two months to over 50 years. The interval between the first exposure and death varied between 16 and 55 years (mean 37.5 years). Among the group of factory workers, where exposure was probably heaviest, the interval was shortest. It was longest among the group living in the neighbourhood of the asbestos factories, where exposure to dust was probably lowest. Table 7 shows the mean age of each group at first exposure and the mean of the interval before death in each group. Although the length of interval

TABLE 7

RELATION BETWEEN TYPE OF EXPOSURE AND LENGTH OF INTERVAL BEFORE DEATH IN 51 PATIENTS IN MESOTHELIOMA SERIES

\begin{tabular}{l|r|c|c}
\hline \multicolumn{1}{|c|}{ Type of Exposure } & No. & $\begin{array}{c}\text { Mean Age at } \\
\text { First Exposure } \\
\text { (years) }\end{array}$ & $\begin{array}{c}\text { Mean Interval } \\
\text { between First } \\
\text { Exposure and } \\
\text { Death } \\
\text { (years) }\end{array}$ \\
\hline $\begin{array}{l}\text { Factory work } \\
\text { Domestic }\end{array}$ & 23 & 22.5 & 29.4 \\
$\begin{array}{l}\text { Laggers and insulators } \\
\text { Living in neighbour- } \\
\text { hood of factory }\end{array}$ & 8 & 11.9 & 37.9 \\
\hline
\end{tabular}

varied between 29.4 and 48.6 years, the mean age at death showed less variation; it was 50.6 years in the group of factory workers and between 55 and 57 years in the other groups.

Asbestos Bodies and Asbestosis in the Mesothelioma Series.-Of the 83 patients in the mesothelioma series, lung tissue was available for examination in forty-three. In four other patients, all certified as suffering from asbestosis, with no lung tissue available, examination of sputum during life revealed the presence of asbestos bodies (Table 8). Both asbestos bodies and histological evidence of asbestosis were found in $\mathbf{1 5}$ of the 24 factory workers and laggers. A further five showed evidence of either asbestos bodies or asbestosis.
Lung tissue was available in only four patients exposed either through relatives or by living in the neighbourhood of asbestos factories. In two, asbestos bodies were present in lung tissue but there was no evidence of asbestosis.

\section{TABLE 8}

EVIDENCE OF ASBESTOS BODIES OR ASBESTOSIS IN 47 CASES OF MESOTHELIOMA WITH LUNG TISSUE OR SPUTUM AVAILABLE FOR EXAMINATION

\begin{tabular}{l|c|c|c}
\hline $\begin{array}{c}\text { History of } \\
\text { Contact } \\
\text { with } \\
\text { Asbestos }\end{array}$ & Asbestosis or Asbestos Bodies & $\begin{array}{c}\text { Lung Tissue } \\
\text { not Available }\end{array}$ \\
\cline { 2 - 3 } & Present & Absent & 23 \\
\hline Positive & 22 & 6 & 13 \\
Negative & 4 & 8 & 0 \\
\hline Untraced & 4 & 3 & 36 \\
\hline Total & 30 & 17 &
\end{tabular}

Among the 12 patients in whom no definite contact with asbestos could be established, there was one, a merchant seaman from South Africa, whose lungs showed both asbestos bodies and asbestosis; he may have had contact either in South Africa or at sea, but his early history could not be established. There were three others in this group who had asbestos bodies in lung tissue without evidence of asbestosis.

Of the seven patients whose histories could not be traced, three had asbestos bodies and histological evidence of asbestosis and one had asbestosis alone.

\section{Discussion}

In the mesothelioma series there are 25 patients in whom no evidence of any exposure to asbestos could be found. A chief source of information was a history taken from a surviving relative. A surprising amount of information was obtained, but in some of those interviewed the memory may have been defective or they may not have known of short periods of exposure during the youth of the deceased. For example, one of the patients was eventually identified as having worked at a large asbestos factory for two months in 1941. This was before he married, and his widow did not know of this episode. It is of interest that asbestos bodies in the lungs were found in only four of this group, and it seems probable that among the remainder there were those who had had no exposure to asbestos.

In the mesothelioma series of patients, both industrial and non-industrial exposures were recognized. Among the men the exposure was predominantly industrial; 22 worked in asbestos factories or as laggers, two were exposed at home, and one lived near the asbestos factory. Among the women only 10 worked in asbestos factories, and a 
further 17 had non-industrial exposures, seven in the home and 10 living near asbestos factories.

There is no evidence that the patients with peritoneal tumours differed in their type of exposure from the patients with pleural tumours. The proportion of positive findings of asbestos bodies or asbestosis was similar in both groups. A higher proportion of women, particularly among the factory workers, was affected by peritoneal tumours, but the difference between the sexes was not statistically significant.

The recent increase in the number of patients diagnosed at the hospital may be partly due to an increased interest in mesothelial tumours and partly to the long interval between first exposure and development of the tumour. Those exposed between 1915 and 1925 might be expected to die from about 1950 onwards. Asbestos imports to the United Kingdom have mounted steeply since 1932 (Leathart, 1964) and its uses are more widely diversified in industry. The increasing proportion of the population exposed to asbestos during the past 30 years may be expected to give rise to an increasing occurrence of mesothelial tumours.

The choice of groups for comparison with the mesothelioma series of patients was not ideal. The number of patients it was possible to trace in the 'rejected' series proved to be very small. The 'inpatient' series, although matched for date of birth and sex, differed from the mesothelioma series in that all were admitted to hospital during 1964. Neither of these groups could be interviewed without knowledge of the disease from which they were suffering. This could have led to bias with under-reporting of exposure to asbestos in the in-patient series. However, in the 'in-patient' series the actual patient was interviewed, and more detailed and reliable histories were obtained than was possible from the relatives of those who had died of mesothelial tumours. There was no evidence that, because of their more recent admission to hospital, the in-patient series was less likely than the mesothelioma series to work in contact with asbestos or to live in closer proximity to asbestos factories.

There seems little doubt that the risk of mesothelioma may arise from both occupational and domestic exposures to asbestos. Wagner and others (1960) described patients with no exposure other than living as a child in the vicinity of the asbestos mines. A high incidence of asbestos plaques of the pleura has been found in the population living near an anthophyllite mine in Finland (Kiviluoto, 1960). More evidence is required of an increased risk to the population living in the neighbourhood of asbestos factories or other areas, such as dockyards, where asbestos is used in quantity.

We should like to thank Dr. D. O'B. Hourihane for his co-operation and for making the results of his investigations available to us.

Our thanks are also due to Professor C. Wilson, Professor V. W. Dix, Dr. N. L. Rusby, and Mr. G. Flavell, F.R.C.S., of the London Hospital and Dr. C. P. Silver of St. Matthew's Hospital for permission to interview their patients; to the general practitioners who collaborated in this enquiry; to the managements of the asbestos factories for arranging access to their records; to Miss Joan Walford for statistical assistance, and to Dr. J. C. Gilson, Professor R. S. F. Schilling, and Dr. W. Smither for their advice and help.

The contents of this paper were communicated to the Conference on the Biological Effects of Asbestos, arranged by the New York Academy of Sciences in October 1964, and will be published in a shorter form in the proceedings of that conference.

\section{REFERENCES}

Fowler, P. B. S., Sloper, J. C., and Warner, E. C. (1964). Brit. med. J., 2, 211 .

Leading article (1964). Ibid., 2, 202.

Hourihane, D. O'B. (1964). Thorax, 19, 268.

Kiviluoto, R. (1960). Acta radiol. (Stockh.), Suppl. 194

Leathart, G. L. (1964). Occup. Hith, (Lond.), 16, 119.

Owen, W. Glyn (1964). Brit. med. J., $2,214$.

Wagner, J. C., Sleggs, C. A., and Marchand, P. (1960). Brit. J. industr. Med., 17, 260. 
APPENDIX

EIGHTY-THREE PATIENTS WITH MESOTHELIAL TUMOURS

\begin{tabular}{|c|c|c|c|c|c|c|c|c|c|c|c|}
\hline $\begin{array}{l}\text { Case } \\
\text { No. }\end{array}$ & $\begin{array}{l}\text { Site of } \\
\text { Primary } \\
\text { Tumour }\end{array}$ & Sex & $\begin{array}{c}\text { Year } \\
\text { of } \\
\text { Birth }\end{array}$ & $\begin{array}{c}\text { Year } \\
\text { of } \\
\text { First } \\
\text { Expo- } \\
\text { sure }\end{array}$ & $\begin{array}{c}\text { Dura- } \\
\text { tion } \\
\text { of } \\
\text { Expo- } \\
\text { sure } \\
\text { (years) }\end{array}$ & $\begin{array}{c}\text { Year } \\
\text { of } \\
\text { Death }\end{array}$ & $\begin{array}{l}\text { How } \\
\text { Diag- } \\
\text { nosed }\end{array}$ & $\begin{array}{l}\text { Asbestos } \\
\text { Bodies } \\
\text { in Lung } \\
\text { Tissue }\end{array}$ & $\begin{array}{l}\text { Patho- } \\
\text { logical } \\
\text { Evidence } \\
\text { of As- } \\
\text { bestosis } \\
\text { in Lung } \\
\text { Tissue }\end{array}$ & $\begin{array}{c}\text { Survival } \\
\text { from } \\
\text { Initial } \\
\text { Symptoms } \\
\text { (months) }\end{array}$ & Relevant History \\
\hline \multicolumn{12}{|c|}{ Section A: Factory workers } \\
\hline 8 & Pleura & $\mathbf{M}$ & 1901 & 1921 & 17 & 1938 & Necropsy & Positive & Positive & $?$ & Brake liner, boiler coverer, asbes- \\
\hline 19 & Peritoneum & $\mathbf{M}$ & 1895 & 1919 & 22 & 1941 & Necropsy & Positive & Positive & $?$ & $\begin{array}{l}\text { Disintegrator and other jobs, } \\
\text { asbestos factory; amosite, croci- } \\
\text { dolite, chrysotile }\end{array}$ \\
\hline 18 & Peritoneum & $\mathbf{F}$ & 1908 & 1925 & 5 & 1947 & Biopsy & $\begin{array}{l}\text { Positive } \\
\text { (sputum) }\end{array}$ & $\mathbf{N} / \mathbf{A}$ & $?$ & $\begin{array}{l}\text { Sectional pipe maker, asbestos } \\
\text { factory, certified asbestotic; main- } \\
\text { ly crocidolite }\end{array}$ \\
\hline 24 & Pleura & $\mathbf{M}$ & 1880 & 1928 & 12 & 1950 & Necropsy & Positive & Negative & 9 & $\begin{array}{l}\text { Used asbestos boarding in railway } \\
\text { carriage construction }\end{array}$ \\
\hline 14 & Peritoneum & $\mathbf{F}$ & 1893 & 1917 & $?$ & 1951 & Necropsy & Negative & Negative & $?$ & Asbestos factory, job unknown \\
\hline 16 & Peritoneum & $\mathbf{F}$ & 1906 & 1922 & 7 & 1951 & Biopsy & $\begin{array}{l}\text { Positive } \\
\text { (sputum) }\end{array}$ & $\mathbf{N} / \mathbf{A}$ & $?$ & $\begin{array}{l}\text { Opener and sectional pipe maker, } \\
\text { asbestos factory, certified asbes- } \\
\text { totic; amosite, crocidolite, chryso- } \\
\text { tile }\end{array}$ \\
\hline 13 & Peritoneum & $\mathbf{F}$ & 1894 & 1915 & 5 & 1955 & Necropsy & Positive & Positive & 12 & $\begin{array}{l}\text { Spinner, asbestos factory, certified } \\
\text { asbestotic; mainly crocidolite }\end{array}$ \\
\hline 11 & Peritoneum & $\mathbf{F}$ & 1895 & 1917 & 1 & 1955 & Biopsy & $\begin{array}{l}\text { Positive } \\
\text { (sputum) }\end{array}$ & $\mathbf{N} / \mathbf{A}$ & 3 & $\begin{array}{l}\text { Sectional pipe maker, asbestos } \\
\text { factory, certified asbestotic; mainly } \\
\text { crocidolite }\end{array}$ \\
\hline 15 & Peritoneum & $\mathbf{F}$ & 1901 & 1918 & $1 \frac{1}{2}$ & 1955 & Biopsy & Positive & $\mathbf{N} / \mathbf{A}$ & 6 & $\begin{array}{l}\text { Spinner, asbestos factory, certified } \\
\text { asbestotic: mainly crocidolite }\end{array}$ \\
\hline 9 & Peritoneum & $\mathbf{F}$ & 1897 & 1919 & 1 & 1956 & Necropsy & Positive & Negative & 3 & $\begin{array}{l}\text { Disintegrator, asbestos factory; } \\
\text { amosite, crocidolite, chrysotile }\end{array}$ \\
\hline 21 & Pleura & $\mathbf{M}$ & 1893 & 1928 & 1 & 1957 & Biopsy & $\mathbf{N} / \mathbf{A}$ & $\mathbf{N} / \mathbf{A}$ & 18 & $\begin{array}{l}\text { Asbestos mixer, north England } \\
\text { asbestos factory }\end{array}$ \\
\hline 12 & Peritoneum & $\mathbf{F}$ & 1918 & 1937 & 2 & 1958 & Biopsy & $\mathbf{N} / \mathbf{A}$ & $\mathbf{N} / \mathbf{A}$ & 18 & $\begin{array}{l}\text { Carder, asbestos factory; mainly } \\
\text { crocidolite }\end{array}$ \\
\hline 5 & Peritoneum & $\mathbf{M}$ & 1908 & 1927 & 30 & 1958 & Necropsy & Positive & Positive & 18 & $\begin{array}{l}\text { Clothing and weaving, asbestos } \\
\text { factory; amosite, crocidolite, } \\
\text { chrysotile }\end{array}$ \\
\hline 7 & Peritoneum & $\mathbf{M}$ & 1925 & 1940 & 4 & 1958 & Biopsy & $\mathbf{N} / \mathbf{A}$ & $\mathbf{N} / \mathbf{A}$ & 3 & $\begin{array}{l}\text { Filter maker for A.R.P. masks, } \\
\text { asbestos factory; mainly croci- }\end{array}$ \\
\hline 20 & Peritoneum & $\mathbf{M}$ & 1907 & 1921 & $1 / 6$ & 1959 & Necropsy & Negative & Negative & 11 & $\begin{array}{l}\text { Filter maker for A.R.P. masks, } \\
\text { asbestos factory; mainly croci- } \\
\text { dolite } \\
\text { Electrode coverer; crocidolite }\end{array}$ \\
\hline 17 & Pleura & $\mathbf{F}$ & 1908 & 1924 & 1 & 1962 & Biopsy & Positive & Negative & $?$ & Spinner, asbestos factory; mainly \\
\hline 6 & Pleura & $\mathbf{M}$ & 1907 & 1942 & 10 & 1962 & Necropsy & Positive & Positive & $?$ & $\begin{array}{l}\text { Delivered chemicals to asbestos } \\
\text { factory; amosite, crocidolite, } \\
\text { chrysotile }\end{array}$ \\
\hline 10 & Peritoneum & $\mathbf{F}$ & 1899 & 1923 & $1 \frac{1}{2}$ & 1963 & Biopsy & Positive & & 5 & $\begin{array}{l}\text { Spinner, asbestos factory; mainly } \\
\text { crocidolite }\end{array}$ \\
\hline 1 & Pleura & $\mathbf{M}$ & 1899 & 1936 & 26 & 1963 & Necropsy & Positive & Positive & $?$ & $\begin{array}{l}\text { Labourer, works and buildings, } \\
\text { asbestos factory; amosite, croci- } \\
\text { dolite, chrysotile }\end{array}$ \\
\hline 23 & Pleura & $\mathbf{M}$ & 1908 & 1925 & $\frac{1}{4}$ & 1963 & Necropsy & Positive & Negative & 8 & $\begin{array}{l}\text { Worked in yard of insulating } \\
\text { contractors }\end{array}$ \\
\hline 3 & Peritoneum & $\mathbf{M}$ & 1911 & 1930 & 2 & 1963 & Necropsy & Positive & Positive & 6 & $\begin{array}{l}\text { Carder, asbestos factory; mainly } \\
\text { crocidolite }\end{array}$ \\
\hline 4 & Peritoneum & $\mathbf{M}$ & 1917 & 1937 & 27 & 1964 & Necropsy & Positive & Positive & 24 & $\begin{array}{l}\text { Disintegrator and other jobs, } \\
\text { asbestos factory; amosite, croci- } \\
\text { dolite, chrysotile }\end{array}$ \\
\hline \multicolumn{12}{|c|}{ Section B: Laggers and insulators } \\
\hline 25 & Pleura & $\mathbf{M}$ & 1874 & 1888 & 53 & 1935 & Necropsy & Negative & Negative & 12 & $\begin{array}{l}\text { Worked in close proximity to boiler } \\
\text { repairer in dockyards }\end{array}$ \\
\hline 28 & Pleura & $\mathbf{M}$ & 1893 & 1910 & 22 & 1955 & Biopsy & $\mathbf{N} / \mathbf{A}$ & $\mathbf{N} / \mathbf{A}$ & & Boiler cleaner and stripper, dock- \\
\hline 22 & Pleura & $\mathbf{M}$ & 1921 & 1937 & 22 & 1959 & Necropsy & Positive & Positive & 9 & Boiler coverer and lagger to various \\
\hline 30 & Pleura & $\mathbf{M}$ & 1908 & 1922 & 39 & 1961 & Biopsy & $\mathbf{N} / \mathbf{A}$ & $\mathbf{N} / \mathbf{A}$ & 25 & $\begin{array}{l}\text { frms } \\
\text { Erecting and fitting central heating }\end{array}$ \\
\hline 27 & Peritoneum & $\mathbf{M}$ & 1908 & 1922 & 36 & 1961 & Necropsy & Positive & Positive & 12 & Boiler coverer and pipe insulator, \\
\hline 26 & Peritoneum & $\mathbf{M}$ & 1911 & 1927 & 34 & 1961 & Necropsy & Positive & Positive & 13 & Lagger and boiler coverer, various \\
\hline 31 & Pleura & $\mathbf{M}$ & 1897 & 1916 & 41 & 1962 & Biopsy & $\mathbf{N} / \mathbf{A}$ & $\mathbf{N} / \mathbf{A}$ & 8 & Intermittently boiler lagger, ship \\
\hline 29 & Pleura & $\mathbf{M}$ & 1912 & 1927 & 34 & 1962 & Biopsy & $\mathbf{N} / \mathbf{A}$ & $\mathbf{N} / \mathbf{A}$ & 10 & $\begin{array}{l}\text { repairs } \\
\text { Installation of hospital sterilizing } \\
\text { equipment }\end{array}$ \\
\hline
\end{tabular}


APPENDIX (continued)

EIGHTY-THREE PATIENTS WITH MESOTHELIAL TUMOURS

\begin{tabular}{|c|c|c|c|c|c|c|c|c|c|c|c|}
\hline $\begin{array}{l}\text { Case } \\
\text { No. }\end{array}$ & $\begin{array}{l}\text { Site of } \\
\text { Primary } \\
\text { Tumour }\end{array}$ & Sex & $\begin{array}{c}\text { Year } \\
\text { of } \\
\text { Birth }\end{array}$ & $\begin{array}{c}\text { Year } \\
\text { of } \\
\text { First } \\
\text { Expo- } \\
\text { sure }\end{array}$ & $\begin{array}{c}\text { Dura- } \\
\text { tion } \\
\text { of } \\
\text { Expo- } \\
\text { sure } \\
\text { (years) }\end{array}$ & $\begin{array}{l}\text { Year } \\
\text { of } \\
\text { Death }\end{array}$ & $\begin{array}{l}\text { How } \\
\text { Diag- } \\
\text { nosed }\end{array}$ & $\begin{array}{l}\text { Asbestos } \\
\text { Bodies } \\
\text { in Lung } \\
\text { Tissue }\end{array}$ & $\begin{array}{l}\text { Patho- } \\
\text { logical } \\
\text { Evidence } \\
\text { of As- } \\
\text { bestosis } \\
\text { in Lung } \\
\text { Tissue }\end{array}$ & \begin{tabular}{|c|} 
Survival \\
from \\
Initial \\
Symptoms \\
(months)
\end{tabular} & Relevant History \\
\hline \multicolumn{12}{|c|}{ Section C: Exposure of relatives } \\
\hline 40 & Pleura & $\mathbf{M}$ & 1912 & 1925 & 11 & 1956 & Biopsy & $\mathbf{N} / \mathbf{A}$ & $\mathbf{N} / \mathbf{A}$ & 27 & $\begin{array}{l}\text { Elder sister worked as spinner at } \\
\text { asbestos factory, died 1946, } \\
\text { certified asbestotic }\end{array}$ \\
\hline 34 & Pleura & $\mathbf{F}$ & 1913 & 1919 & 2 & 1957 & Biopsy & $\mathbf{N} / \mathbf{A}$ & $\mathbf{N} / \mathbf{A}$ & 14 & $\begin{array}{l}\text { Elder sister employed as spinner, } \\
\text { looked after patient as child }\end{array}$ \\
\hline 38 & Pleura & $\mathbf{F}$ & 1895 & 1919 & 41 & 1960 & Biopsy & $\mathbf{N} / \mathbf{A}$ & $\mathbf{N} / \mathbf{A}$ & 15 & $\begin{array}{l}\text { For several years husband worked } \\
\text { in ship's engine room, close } \\
\text { proximity to lagging operations }\end{array}$ \\
\hline 37 & Pleura & $\mathbf{F}$ & 1905 & 1925 & 14 & 1960 & Biopsy & $\mathbf{N} / \mathbf{A}$ & $\mathbf{N} / \mathbf{A}$ & 3 & $\begin{array}{l}\text { Husband worked as boiler coverer; } \\
\text { overalls brought home for washing }\end{array}$ \\
\hline 35 & Peritoneum & $\mathbf{F}$ & 1890 & 1921 & 21 & 1960 & Necropsy & Positive & Negative & 24 & $\begin{array}{l}\text { Husband foreman and executive at } \\
\text { asbestos factory }\end{array}$ \\
\hline 33 & Pleura & $\mathbf{F}$ & 1916 & 1930 & 4 & 1961 & Necropsy & Negative & Negative & $?$ & $\begin{array}{l}\text { Husband a docker; frequently } \\
\text { handled 'white' asbestos }\end{array}$ \\
\hline 39 & Pleura & $\mathbf{M}$ & 1919 & 1928 & 2 & 1961 & Biopsy & N/A & $\mathbf{N} / \mathbf{A}$ & 18 & $\begin{array}{l}\text { Elder sister worked as spinner at } \\
\text { asbestos factory and suffers from } \\
\text { asbestosis }\end{array}$ \\
\hline 32 & Pleura & $\mathbf{F}$ & 1900 & 1941 & 5 & 1963 & Biopsy & $\mathbf{N} / \mathbf{A}$ & $\mathbf{N} / \mathbf{A}$ & 18 & $\begin{array}{l}\text { Daughter worked in asbestos factory } \\
\text { for } 5 \text { years; patient washed her } \\
\text { overalls }\end{array}$ \\
\hline 36 & Peritoneum & $\mathbf{F}$ & 1889 & 1912 & 18 & 1963 & Biopsy & $\mathbf{N} / \mathbf{A}$ & $\mathbf{N} / \mathbf{A}$ & 15 & $\begin{array}{l}\text { Husband railway carriage builder; } \\
\text { lined compartments with asbestos } \\
\text { sheeting; work clothes washed at } \\
\text { home }\end{array}$ \\
\hline \multicolumn{12}{|c|}{ Section D: Neighbourhood cases } \\
\hline 44 & Pleura & $\mathbf{F}$ & 1905 & 1913 & 7 & 1959 & Biopsy & $\mathbf{N} / \mathbf{A}$ & $\mathbf{N} / \mathbf{A}$ & 8 & $\begin{array}{l}\text { Lived within } \frac{1}{2} \text { mile of present site } \\
\text { of asbestos factory }\end{array}$ \\
\hline 48 & Pleura & $\mathbf{M}$ & 1922 & 1922 & 16 & 1960 & Biopsy & $\mathbf{N} / \mathbf{A}$ & $\mathbf{N} / \mathbf{A}$ & 17 & $\begin{array}{l}\text { Lived within } \frac{1}{2} \text { mile of present site } \\
\text { of asbestos factory }\end{array}$ \\
\hline 42 & Pleura & $\mathbf{F}$ & 1889 & 1913 & 48 & 1961 & Biopsy & Positive & Negative & 15 & $\begin{array}{l}\text { Lived within } 100 \text { yards of present } \\
\text { site of asbestos factory }\end{array}$ \\
\hline 50 & Pleura & $\mathbf{F}$ & 1903 & 1908 & 6 & 1961 & Biopsy & $\mathbf{N} / \mathbf{A}$ & $\mathbf{N} / \mathbf{A}$ & 13 & $\begin{array}{l}\text { Lived within } \frac{1}{2} \text { mile of old site of } \\
\text { asbestos factory }\end{array}$ \\
\hline 43 & Pleura & $\mathbf{F}$ & 1905 & 1913 & 13 & 1961 & Biopsy & $\mathbf{N} / \mathbf{A}$ & $\mathbf{N} / \mathbf{A}$ & 4 & $\begin{array}{l}\text { Lived within } \frac{1}{2} \text { mile of present site } \\
\text { of asbestos factory }\end{array}$ \\
\hline 47 & Pleura & $\mathbf{F}$ & 1917 & 1917 & 10 & 1961 & Biopsy & $\mathbf{N} / \mathbf{A}$ & $\mathbf{N} / \mathbf{A}$ & 16 & $\begin{array}{l}\text { Lived within } 200 \text { yards of present } \\
\text { site of asbestos factory }\end{array}$ \\
\hline 64 & Pleura & $\mathbf{F}$ & 1899 & 1907 & 6 & 1962 & Biopsy & Negative & Negative & 5 & $\begin{array}{l}\text { Lived within mile of old site of } \\
\text { asbestos factory }\end{array}$ \\
\hline 71 & Pleura & $\mathbf{F}$ & 1899 & 1907 & 6 & 1962 & Biopsy & $\mathbf{N} / \mathbf{A}$ & N/A & 12 & $\begin{array}{l}\text { Lived within } \frac{1}{2} \text { mile of old site of } \\
\text { asbestos factory }\end{array}$ \\
\hline 41 & Pleura & $\mathbf{F}$ & 1900 & 1913 & 32 & 1962 & Biopsy & $\mathbf{N} / \mathbf{A}$ & $\mathbf{N} / \mathbf{A}$ & 29 & $\begin{array}{l}\text { Lived within } \frac{1}{2} \text { mile of present site } \\
\text { of asbestos factory }\end{array}$ \\
\hline 45 & Pleura & $\mathbf{F}$ & 1900 & 1913 & 7 & 1962 & Biopsy & $\mathbf{N} / \mathbf{A}$ & $\mathbf{N} / \mathbf{A}$ & 9 & Lived within $\frac{1}{2}$ mile of present site \\
\hline 46 & Pleura & $\mathbf{F}$ & 1907 & 1913 & 7 & 1963 & Biopsy & $\mathbf{N} / \mathbf{A}$ & $\mathbf{N} / \mathbf{A}$ & 7 & $\begin{array}{l}\text { Lived within } \frac{1}{2} \text { mile of present site } \\
\text { of asbestos factory }\end{array}$ \\
\hline \multicolumn{12}{|c|}{ Section E: No history of contact with asbestos } \\
\hline 65 & Pleura & $\mathbf{F}$ & 1900 & & & 1947 & Necropsy & Positive & Negative & 7 & $\begin{array}{l}\text { Worked as nursemaid to manager } \\
\text { of gas works in East London; } \\
\text { asbestos insulation used in works }\end{array}$ \\
\hline 68 & Peritoneum & $\mathbf{F}$ & 1902 & & & 1954 & Necropsy & & & 5 & $\begin{array}{l}\text { Shorthand-typist and housewife; } \\
\text { lived Ilford area }\end{array}$ \\
\hline 49 & Pleura & $\mathbf{M}$ & 1895 & & & 1954 & Biopsy & $\mathbf{N} / \mathbf{A}$ & $\mathbf{N} / \mathbf{A}$ & $?$ & $\begin{array}{l}\text { Baker's roundsman, army, general } \\
\text { labourer, publican for } 30 \text { years in } \\
\text { East End of London }\end{array}$ \\
\hline 75 & Pleura & $\mathbf{F}$ & 1899 & & & 1955 & Biopsy & N/A & $\mathbf{N} / \mathbf{A}$ & $?$ & $\begin{array}{l}\text { Munitions work before marriage, } \\
\text { then housewife; lived Waltham } \\
\text { Abbey, Essex }\end{array}$ \\
\hline 74 & Peritoneum & $\mathbf{F}$ & 1904 & & & 1955 & Necropsy & Negative & Negative & 27 & $\begin{array}{l}\text { Tailoress and housewife in East } \\
\text { End of London }\end{array}$ \\
\hline 62 & Pleura & $\mathbf{M}$ & 1899 & & & 1955 & Necropsy & Negative & Positive & 28 & $\begin{array}{l}\text { Employed as luteman and greaser, } \\
\text { Beckton gas works 36 years; } \\
\text { persistent discharging sinus R. } \\
\text { side of chest following empyema } \\
1925 \text {, acute chest infection 1953, } \\
\text { subsequent thoracoplasty but } \\
\text { deteriorated from this date }\end{array}$ \\
\hline
\end{tabular}

(continued) 
APPENDIX (continued)

EIGHTY-THREE PATIENTS WITH MESOTHELIAL TUMOURS

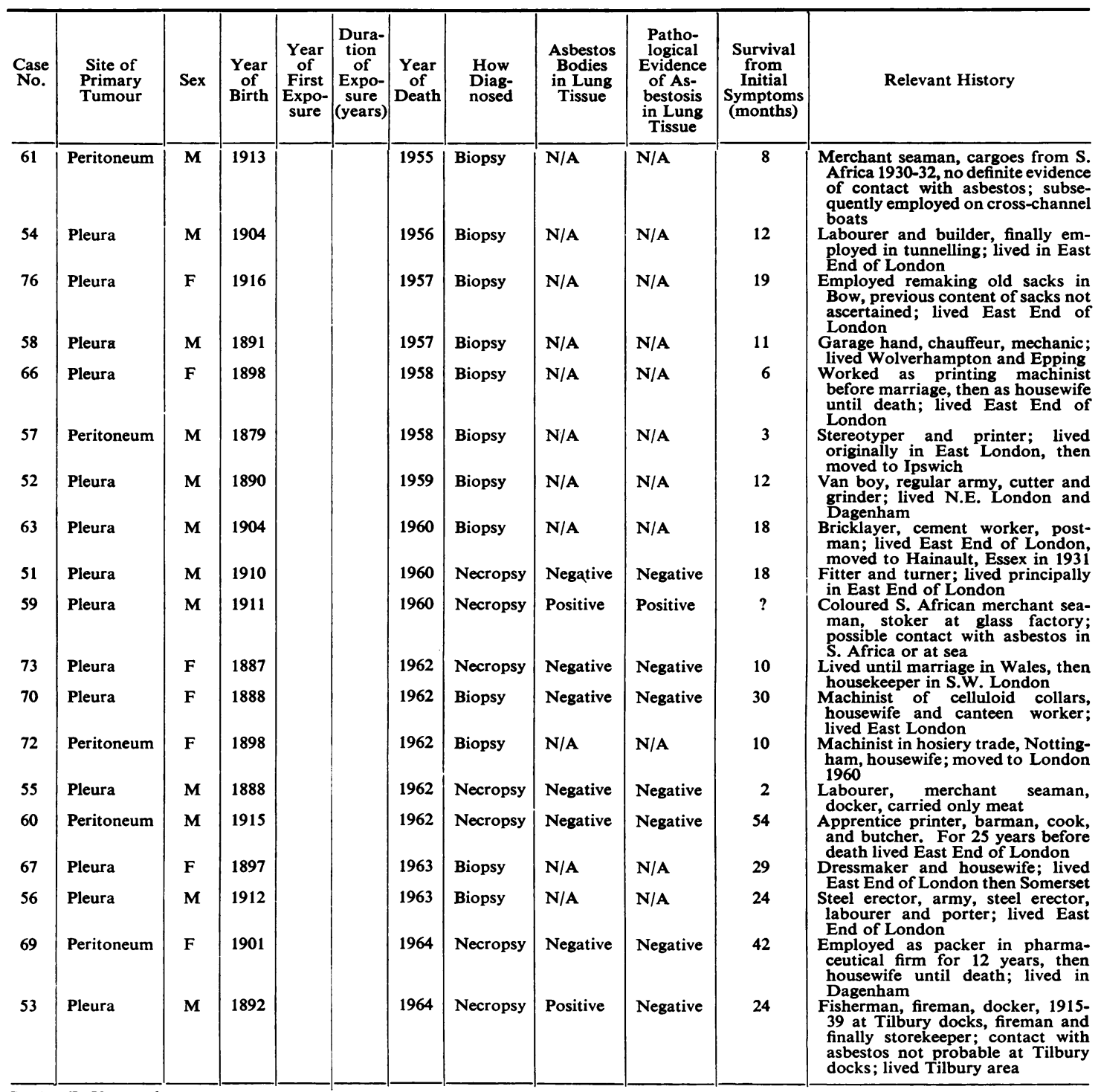

Section F: Untraced cases

\begin{tabular}{l|l|c|c|}
78 & Pleura & F & 1893 \\
83 & Pleura & M & 1860 \\
81 & Pleura & M & 1877 \\
80 & Pleura & M & 1900 \\
82 & Pleura & M & 1893 \\
77 & Peritoneum & F & 1910 \\
79 & Pleura & F & 1878
\end{tabular}

\begin{tabular}{c|c|c|c}
1917 & Necropsy & $?$ & Positive \\
1922 & Necropsy & Negative & Negative \\
1925 & Necropsy & Negative & Negative \\
1936 & Necropsy & Negative & Negative \\
1938 & Necropsy & Positive & Positive \\
1945 & Necropsy & Positive & Positive \\
1955 & Necropsy & Positive & Positive
\end{tabular}

Not traced

Not traced

Not traced

Not traced

Not traced

Not traced

Not traced 